\title{
Bromeliad tanks are unique habitats for microbial communities involved in methane turnover
}

\author{
Franziska B. Brandt • Guntars O. Martinson • \\ Ralf Conrad
}

Received: 8 March 2016 / Accepted: 8 July 2016 / Published online: 23 July 2016

(C) The Author(s) 2016. This article is published with open access at Springerlink.com

\begin{abstract}
Background and aims Tank bromeliads collect organic matter and rainwater (= tank slurry) between their densely arranged leaf axils for their nutrient demand. Diverse communities of microorganisms inhabit these tanks and are responsible for the breakdown of organic matter. Anaerobic degradation results in the release of substantial amounts of methane. We hypothesized that each individual bromeliad harbors its own microbial community, which is affected by chemical tank-slurry properties. We further hypothesized that methanotrophic bacteria inhabit bromeliad tank slurries, potentially able to oxidize the produced $\mathrm{CH}_{4}$.

Methods We investigated communities of Bacteria, Archaea, methanogenic and methanotrophic microorganisms measuring their abundance (qPCR) and composition (TRFLP) within eight bromeliad tanks of the species Werauhia gladioliflora sampled in a Costa Rican lowland forest. Tank slurries were analyzed for $\mathrm{pH}$, carbon, nitrogen, oxygen and fatty acid concentrations. Methane oxidation rates were determined in five bromeliad tank slurries.
\end{abstract}

Responsible Editor: Paul Bodelier.

Electronic supplementary material The online version of this article (doi:10.1007/s11104-016-2988-9) contains supplementary material, which is available to authorized users.

F. B. Brandt · G. O. Martinson $(\bowtie) \cdot$ R. Conrad Max-Planck-Institute for Terrestrial Microbiology, Karl-von-Frisch Straße 10, 35043 Marburg, Germany e-mail: guntars.martinson@mpi-marburg.mpg.de
Results Our results showed that microbial communities differed between plants and were affected by chemical tank slurry properties. Further, not only methanogenic archaea but also methanotrophic bacteria were detected in the tanks of all bromeliad plants, the latter being potentially able to aerobically oxidize between 25 and $62 \mu \mathrm{g} \mathrm{CH}_{4} \mathrm{gdw}^{-1} \mathrm{~h}^{-1}$.

Conclusion Our results indicate that every bromeliad tank is a unique island with respect to its resident microbial community. The presence of methanogens and active methanotrophs in all tank slurries further indicates the potential for both methane formation and methane oxidation.

Keywords Bromeliad B Bacteria $\cdot$ Archaea .

Methanogens $\cdot$ Methanotrophs $\cdot$ Methane oxidation

\section{Introduction}

The Bromeliaceae represent one of the largest neotropical families of flowering plants containing about 58 genera with ca. 3140 species (Givnish et al. 2011; Balke et al. 2008). The plants grow terrestrially and epiphytically throughout neotropical forest ecosystems. Their densely arranged leaves form tanks that efficiently collect wind-borne particles, leaf litter and rainwater (= tank slurry) for their nutrient demand, and highly increase the amount of stored carbon and water in the canopies of neotropical forests (Nadkarni 1994). Diverse communities of macro- and microorganisms inhabit these tanks and are responsible for the 
breakdown of tank organic matter, the release of plantavailable nutrients (Ngai and Srivastava 2006) and the emission of substantial amounts of $\mathrm{CH}_{4}$ (Martinson et al. 2010) and $\mathrm{CO}_{2}$ (Atwood et al. 2013). Tank bromeliads were used as natural model systems to study food web structures (Kitching 2001; Srivastava 2006; Srivastava et al. 2008; Brouard et al. 2011), animal richness (Richardson 1999), activity and distribution of (aquatic) invertebrates (Carrias et al. 2001; Marino et al. 2013) and microorganisms (Carmo et al. 2014). Many different bacteria and archaea, which are commonly found in soils, were also detected in Ecuadorian and Costa Rican tank bromeliad slurries (Goffredi et al. 2011a, 2011b; Martinson et al. 2010). Due to their high abundance tank bromeliads may therefore represent important habitats for microorganisms involved in the cycling of carbon and nitrogen (Goffredi et al. 2011b). Recently, Carmo et al. (2014) observed a large variation in the community structure when investigating the bacteria in the tank water of different Neoregelia cruenta bromeliads. Similar results were reported by Farjalla et al. (2012) evaluating the microbial community in the tank water of four bromeliad species. They showed that bacteria had no habitat association and thus concluded stochastic colonization processes. Environmental controls on microbial community composition in bromeliad tanks have hardly been investigated. Previous studies have shown that exposure to sun or shade affects the composition and diversity of aquatic insect in the water of bromeliads (Lopez and Rios 2001). However, Carmo et al. (2014) reported that bacterial communities in tank water showed no grouping by the environmental factors tested (e.g season, sun exposure). The bacterial communities in Costa Rican tank bromeliads were affected by acid-base conditions (Goffredi et al. 2011b). However, it should be noted that sampling strategies were different in previous studies using either the tank water (Carmo et al. 2014; Farjalla et al. 2012) or tank slurry to investigate bacterial communities (Goffredi et al. 2011b). These differences complicate a direct comparison between the studies and may possibly lead to an underestimation or exclusion of resident microbial organisms.

This is the first study investigating the bacterial and archaeal microbial communities as well as the functional groups of methanogens and methanotrophs in the tank slurry of individuals of the species Werauhia gladioliflora. We tested the following hypothesis: (1) each bromeliad plant represents a unique island with respect to its microbial community driven by chemical tank-slurry properties. We further investigated the variability of microbial community composition and abundance within single bromeliads. Since tank bromeliads contribute to the methane cycle in neotropical forests (Martinson et al. 2010) we further hypothesized (2) that methanotrophic bacteria inhabit bromeliad tank slurries, potentially able to oxidize the produced $\mathrm{CH}_{4}$.

In order to reduce potential variability of microbial communities, we tested our hypotheses by selecting eight mature tank bromeliads of the species Werauhia gladioliflora, which were of similar size and were grown epiphytically in the same habitat within one hectare of a Costa Rican secondary lowland forest. The abundance and composition of microbial groups were determined targeting the bacterial and archaeal 16S rRNA gene as well as the methanogenic and methanotrophic marker genes $m c r A$ and $p m o A$, respectively, using quantitative PCR (qPCR) and terminal restriction fragment length polyphormism (TRFLP). We measured the main chemical tank-slurry properties for each individual plant ( $\mathrm{pH}$, oxygen, carbon, nitrogen and fatty acid concentrations) and tested their explanatory power for microbial communities. The potential of aerobic methane oxidation was further determined in five tank slurries using incubation experiments.

\section{Material and methods}

Sampling site and chemical analysis

The field station La Gamba, situated in the southwest of Costa Rica on the edge of the National Park Piedras Blancas (N 8 $42^{\prime} 61^{\prime \prime}$, W 83 $12^{\circ} 97^{\prime \prime}$ ) encircles an area of $142 \mathrm{~km}^{2}$ and is one of the last pristine rainforests in the lowlands at the Pacific coast in Central America. The climate in this region is dominated by a high rainfall (6100 $\mathrm{mm} \mathrm{y}^{-1}$; Hofhansl et al. 2014). The area around the field station is dominated by tank bromeliads of the genus Werauhia (syn. Vriesea).

For this study, we collected eight accessible and epiphytically grown tank bromeliads $(\mathrm{A}-\mathrm{H})$ of the species Werauhia gladioliflora at breast height in an area of approximately 1 ha next to the field station in May 2012 during the wet season. Since we focused on microorganisms which are involved in the methane cycle we sampled during the wet season as water-filled bromeliads enhance the creation of anoxic niches and therefore 
methane formation. The plant height and diameter ranged between $82-94 \mathrm{~cm}$ and $130-140 \mathrm{~cm}$, respectively. Tank bromeliads were carefully detached from their host trees avoiding loss of water or debris. The tank slurry is defined here as the impoundments of rainwatersoaked organic debris located between tank bromeliad leaf axils. For comparison between plants, tank slurries from three different leaf axils were sampled from each of the eight different plants (e.g. A1, A2, A3). For comparison within plants, four out of the eight bromeliads were chosen and three additional leaf axils at opposite position were sampled. For molecular analysis we took sample volumes of $2 \mathrm{~g}$ in 2-ml Eppendorf microcentrifuge tubes and for incubation experiments 5-10 $\mathrm{g}$ in 50-ml Falcon tubes for five out of the eight individuals. Additionally, three soil samples were taken from the study site and used for TRFLP analysis.

Tank slurry and soil samples were used for chemical and molecular characterization

Dissolved oxygen concentration in the slurry of the central tank was directly measured in the field by a GMH 3630 Digital Oxymeter (Greisinger). The pH of each tank slurry was measured using a pocket-sized $\mathrm{pH}$ meter (HI98103 Checker®, Hanna Instruments). Tank slurries were immediately transported in cooled state $\left(4{ }^{\circ} \mathrm{C}\right)$ to the Max-Planck-Institute for Terrestrial Microbiology in Marburg, Germany and then stored frozen at $-20{ }^{\circ} \mathrm{C}$ until analysis. The supernatant of centrifuged tank slurry was filtered through cellulose membranes $(0.2 \mu \mathrm{m})$ and analyzed for fatty acids and ion concentrations using high performance liquid chromatography (HPLC; Sykam) with refractive index and UV detectors and ion chromatography (Sykam), respectively (Krumböck and Conrad 1991; Bak et al. 1991). Fatty acid and ion concentration was calculated using dilution series of external standards (Sigma-Aldrich, Carl Roth). Total carbon and nitrogen concentration of tank slurries and soil samples were analyzed on a CHNS-elemental analyzer (Analytical Chemical Laboratory, University of Marburg).

Molecular analyses

DNA was extracted from $0.3 \mathrm{~g}$ (fresh weight) tank slurry using the NucleoSpin ${ }^{\circledR}$ Soil Kit (Machery-Nagel) according to the manufacturer's protocol. The DNA was dissolved in $50 \mu \mathrm{L}$ nuclease-free water and checked for quality and quantity using a ND1000 spectrophotometer (NanoDrop). DNA was used for all subsequent molecular analyses (qPCR, TRFLP).

Polymerase chain reactions (PCR) for TRFLP analysis targeted bacterial and archaeal 16S rRNA genes as well as the methanogenic marker gene $m c r A$, coding for the methyl coenzyme $\mathrm{M}$ reductase subunit $\mathrm{A}$, and the methanotrophic marker gene pmoA, coding for the methane monooxygenase subunit A. Primer combinations used in the study were: $27 \mathrm{f} / 907 \mathrm{r}$ for Bacteria (Osborne et al. 2005; Muyzer et al. 1995) with FAMlabeled forward primer; 109f/934r for Archaea (Großkopf et al. 1998) with FAM-labeled reverse primer; MCRf/MCRr (Springer et al. 1995) for methanogens with FAM- labeled forward primer; A189f/mb661r (Costello and Lidstrom 1999) for methanotrophs with FAM-labeled forward primer. PCR was carried out in a total volume of $50 \mu \mathrm{L}$, containing $200 \mu \mathrm{M}$ desoxynucleotriphosphates (Fermentas), $1 \times$ GoFlexiGreen Buffer (Sigma- Aldrich), $10 \mu \mathrm{g}$ Bovine Serum Albumin (BSA; Roche), 1 U GoTaq DNA Polymerase (Sigma-Aldrich), $0.5 \mu \mathrm{M}$ of each primer pair, $1.5 \mathrm{mM} \mathrm{MgCl}_{2}$ (Promega) and $20 \mathrm{ng}$ template DNA. The PCR reaction was carried out for $94^{\circ} \mathrm{C}$ for 3 min followed by 22 cycles for bacterial and 30 cycles for archaeal, $m c r A$ and $p m o A$ gene amplification of $94{ }^{\circ} \mathrm{C}$ for $30 \mathrm{~s}, 52{ }^{\circ} \mathrm{C}$ for $45 \mathrm{~s}, 72{ }^{\circ} \mathrm{C}$ for $90 \mathrm{~s}$ and a single step of final elongation of $72^{\circ} \mathrm{C}$ for $5 \mathrm{~min}$. PCR products were analyzed by $1.5 \%$ agarose gelelectrophoresis and visualized by staining with Gel $\operatorname{Red}^{\mathrm{TM}}$ (Biotium) for $30 \mathrm{~min}$. Bands were cut out and purified using Wizard® SV Gel and PCR Clean-Up System (Promega) according to the manufacturer's protocol. Afterwards $100 \mathrm{ng}$ of purified PCR product was digested in a total volume of $10 \mu \mathrm{L}$ with 2.5 Units of restriction enzyme and the provided reaction buffer with a $1 \times$ final concentration. The archaeal $16 \mathrm{~S}$ rRNA and the $p m o A$ amplicons were digested for $6 \mathrm{~h}$ at $36^{\circ} \mathrm{C}$ using TaqI enzyme (Promega), 16S bacterial amplicons were digested at $37{ }^{\circ} \mathrm{C}$ for $15 \mathrm{~min}$ using the MSPI Fast Digest ${ }^{\circledR}$ restriction enzyme (Fermentas). The $m c r A$ amplicons were digested with Sau96I FastDigest ${ }^{\circledR}$ (Fermentas) for $15 \mathrm{~min}$ at $36{ }^{\circ} \mathrm{C}$. All samples were purified using the SigmaSpin Post-Reaction Clean-up Columns (Sigma-Aldrich) according to the manufacture's protocol. The size separation was conducted on an ABI PRISM 3130 capillary Genetic Analyzer (Applera) using the software Genescan 4.0 (Applied Biosystems). The TRFLP data were obtained by 
comparison with an internal DNA standard (X-rhodamine MapMarker® 1000, BioVentures,

Murfreesboro). The resulting TRFLP profiles were standardized as described in Dunbar et al. (2001) using integrated peak area. Standardization often eliminates peaks from profiles with a large total peak area by reducing some peak area below the threshold. In brief, the sample with the smallest DNA quantity (total fluorescence) and the sample with the largest DNA quantity were used to determine a correction factor (the quotient of total fluorescence of the sample with the smallest DNA quantity / total fluorescence of the sample with a larger DNA quantity). This factor was then multiplied with each peak of the DNA profiles with high total fluorescence. Peaks which were then below the $1 \%$ threshold were deleted. The absolute numbers of bacterial and archaeal 16S rRNA, mcrA and pmoA genes were determined by quantitative PCR (qPCR) using the primer combination Ba519f/Ba907r (Stubner 2002) for bacteria, Ar364f/Ar934br (Burggraf et al. 1997/ Großkopf et al. 1998) for archaea, MCRf/MCRr (Springer et al. 1995) for methanogens and A189F/ mb661 (Costello and Lidstrom 1999) for methanotrophs. The qPCR was set up in 96-well microtiter plates (BioRad) using a SYBR green I assay. Each qPCR reaction contained in a total volume of $25 \mu \mathrm{L} 1 \times$ SYBR $®$ Green Ready Mix ${ }^{\mathrm{TM}}$ (Sigma), $3 \mathrm{mM} \mathrm{MgCl}_{2}$ (Sigma), $0.66 \mu \mathrm{M}$ of each primer and $1 \mu \mathrm{M}$ FITC (fluorescein isothiocyanat, BioRad) as well as $2 \mu \mathrm{L}$ of template. Technical replicates were done using 1:10 and 1:100 dilutions of the template DNA. Negative controls without matrix DNA were run in parallel to ensure purity of the used reagents. For all qPCR assays, standards containing known numbers of DNA copies of the target gene were used. The quantification standard was applied in a dilution series with $10^{1}-10^{7}$ gene copies. Thermoprofiles for the quantification of the archaeal 16S rRNA gene copies and mcrA gene copies are described by Angel et al. 2011. The quantification of the bacterial 16S rRNA gene was done using the following thermoprofile: initial denaturation $94^{\circ} \mathrm{C}$ for $8 \mathrm{~min}$, then 45 cycles of $94{ }^{\circ} \mathrm{C}$ for $20 \mathrm{~s}, 50^{\circ} \mathrm{C}$ for $20 \mathrm{~s}$ and $72{ }^{\circ} \mathrm{C}$ for $50 \mathrm{~s}$. The quantification of $p m o A$ genes was performed with the following thermoprofile:initial denaturation step of $94{ }^{\circ} \mathrm{C}$ for $6 \mathrm{~min}$, then 50 cycles of $94{ }^{\circ} \mathrm{C}$ for $25 \mathrm{~s}, 65.5^{\circ} \mathrm{C}$ for $20 \mathrm{~s}$ and $72{ }^{\circ} \mathrm{C}$ for $35 \mathrm{~s}$ for annealing and signal reading. After each quantification a melting curve was performed to ensure the purity of the PCR products.
Methane oxidation

Considering that microbial communities showed no differences within individual plants we used tank slurries of various leaf axils from one plant. Five individual tank bromeliads (A, B, D, F, H) were used to determine aerobic methane oxidation rates. Tank slurries (5-10 g) were incubated in sterile $120 \mathrm{ml}$ serum bottles closed with gas-tight gray butyl stoppers at $25^{\circ} \mathrm{C}$ under aerobic conditions with $1 \% \mathrm{CH}_{4}$ (Messer) in the headspace. Tank slurries were wet (gravimetric water content $87 \pm 2 \%$ ) but not covered with water. Gas samples were taken immediately after the addition of $\mathrm{CH}_{4}$ and then after 8,24 and $32 \mathrm{~h}$ of incubation using a gas-tight pressure lock syringe (Vici) and analyzed using a gas chromatograph with a flame ionization detector (Shimadzu). Methane oxidation rates $\left(\mu \mathrm{g} \mathrm{CH}_{4}\right.$ $\mathrm{gdw}^{-1} \mathrm{~h}^{-1}$ ) were calculated between 0 and $24 \mathrm{~h}$ of incubation for individual A, B, F, H and between 8 and $32 \mathrm{~h}$ for individual $\mathrm{D}$ using linear regression.

Statistical analysis

All statistical analyses were conducted in $\mathrm{R}$ version 2.10.1 (R Core Team 2013). Data of qPCR and chemical properties were tested for normality by Kolmogorov-Smirnov test and for homogeneity of variance by Levene's test. If necessary, normal distribution was achieved by log-transformation of the data. Means were compared using one-way analysis of variance (ANOVA) followed by Tukey's post hoc test. Non-metric-multidimensional scaling analysis (NMDS) of microbial community composition was performed based on TRFLP data using the BrayCurtis dissimilarity index. For NMDS analysis we reported a stress value (in \%) indicating the lack of the fit between the dimensional mapping of the dissimilarities and the original dissimilarities. Differences between community compositions within a tank bromeliad and among tank bromeliads were investigated using permutational multivariate analysis of variance (Permanova) based on TRFLP results. Microbial community structure was related to tank slurry properties using canonical correspondence analyses (CCA). Variables which were highly different between tank bromeliads (carbon, nitrogen, oxygen concentration and $\mathrm{pH} ; P<0.001$; Table 1) were included in the CCA model for which significance was tested using ANOVA. The relative contribution 
Table 1 Differences in environmental variables among the eight tank bromeliad slurries of $W$. gladioliflora were determined by a one-way analysis of variance (ANOVA)

\begin{tabular}{llll}
\hline Variable & df & $\mathrm{F}$ & $P$-value \\
\hline $\mathrm{pH}$ & 7 & 14.0 & $<0.001^{*}$ \\
$\mathrm{C}_{\text {tot }}(\%)$ & 7 & 14.5 & $<0.001^{*}$ \\
$\mathrm{~N}_{\text {tot }}(\%)$ & 7 & 14.6 & $<0.001^{*}$ \\
Oxygen $(\%)$ & 7 & 17.0 & $<0.001^{*}$ \\
Acetate $(\mathrm{mM})$ & 7 & 2.3 & 0.08 \\
Lactate $(\mathrm{mM})$ & 7 & 1.4 & 0.29 \\
\hline
\end{tabular}

$*$ = significant

of each variable to the total constrained variation was calculated by variation partitioning according to Borcard et al. (1992) and Legendre (2008). Linear regression was used to test for a relationship between copy numbers of the bacterial $16 \mathrm{~S}$ rRNA, archaeal 16S rRNA, mcrA and $p m o A$ gene to tank slurry properties carbon, nitrogen, oxygen, $\mathrm{pH}$ ). ANOVA was done using the stats package. NMDS, Permanova and CCA analyses were done using package vegan. All levels of significance were defined at $P<0.05$.

\section{Results}

Tank slurry of Werauhia gladioliflora

The tank slurries showed total carbon and nitrogen concentrations of $39.8 \pm 6.9 \%$ and $1.7 \pm 0.3 \%$ (Supplementary Table S1), respectively, which differed between individual plants (Table 1). By comparison, the total carbon content of the adjacent soil was eight times lower $(4.9 \pm 1.8 \%)$ and the total nitrogen concentration six times lower $(0.3 \pm 0.1 \%)$. The $\mathrm{pH}$ of tank slurry and the oxygen concentration of tank water ranged between $\mathrm{pH}$ 4.6-6.2 and 2.9-9.6 $\mathrm{mg} \mathrm{O}_{2} / \mathrm{L}$, respectively, and differed between individual tank bromeliads (Table 1). Concentrations of lactate, acetate and formate ranged between $0.01-2.93 \mathrm{mM}$, $0.02-0.47 \mathrm{mM}$ and $0.05-1.15 \mathrm{mM}$, respectively (Supplementary Table S1). Concentrations of fatty acids did not differ significantly between the individual tank bromeliads except formate (Table 1). Nitrate was not detectable in any sample.
Microbial communities in Werauhia gladioliflora

Bacterial 16S rRNA gene copies ranged from $3.7 \times 10^{10}$ to $1.8 \times 10^{11}$ copies $\mathrm{gdw}^{-1}$ (Fig. 1 ). Archaeal $16 \mathrm{~S}$ rRNA gene copy numbers were one order of magnitude lower than bacterial gene copy numbers. The functional marker gene mcrA showed more than $10^{9}$ copies in seven bromeliads (Fig. 1). The pmoA marker gene was determined in five individual tank slurries with more than $10^{8}$ copies (Fig. 1). Significantly lower pmoA gene copies (< $5 \times 10^{6}$ gene copies $\mathrm{gdw}^{-1}$ ) were detected in tank bromeliad individuals $\mathrm{E}$ and $\mathrm{G}$. The latter one showed significantly lower archaeal 16S rRNA gene and mcrA gene copies as well (Fig. 1). Within individual plants no significant differences were observed between copy numbers of bacterial and archaeal 16S rRNA as well as $m c r A$ genes (Supplementary Table S2). Solely, the $p m o A$ gene copy numbers within individual $\mathrm{D}$ were significantly different (Supplementary Table S2).

Linear regression was used to test the relationship between copy numbers of the bacterial 16S rRNA, archaeal 16S rRNA, mcrA and pmoA gene and tank slurry properties (carbon, nitrogen, oxygen, $\mathrm{pH}$ ). Solely the number of $p m o A$ marker genes correlated significantly with the oxygen concentration in the bromeliad tanks. With increasing oxygen concentration the abundance of the methanotrophic community apparently increased in tank slurries of W. gladioliflora (Fig. 2a).

Within individual tank bromeliads no differences were detected between microbial community compositions targeting the bacterial 16S rRNA gene, except for individual C (Supplementary Table S2). Among tank bromeliads bacterial, archaeal as well as methanogenic and methanotrophic community composition differed. This is demonstrated by the $P$-values of the Permanova analysis which were significant for the archaeal $(P=0.004)$ and methanotrophic $(P=0.002)$ community and highly significant for the bacterial and methanogenic community $(P=0.0009)$. The differences of the $P$ values were also indicated in NMDS-plots. The bacterial and methanogenic communities displayed a more distinct clustering between individual plants (Fig. 3 a, c) than the archaeal or methanotrophic communities (Fig. 3 b, d). The archaeal and methanotrophic communities were represented by TRFs which were found in similar abundances in most of the tank bromeliads (Supplementary Fig. S1). For instance, the archaeal community was throughout dominated by a 393-bp TRF. In 7 bromeliads the methanotrophic community 


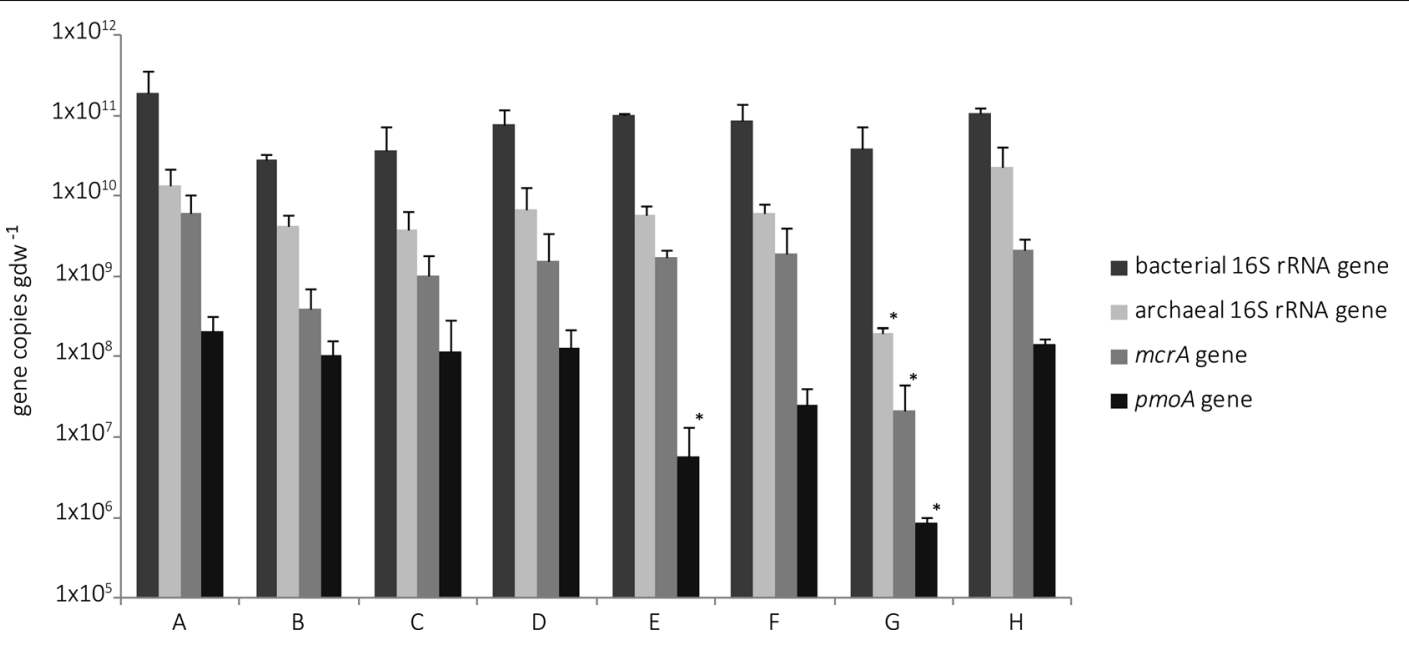

Fig. 1 Gene copy numbers of bacterial, archaeal, methanogenic and methanotropic communities in the slurry of eight individual tank bromeliads of the species $W$. gladioliflora targeting the bacterial and archaeal 16S rRNA gene and the methanogenic and methanotrophic marker gene mcrA and $p m o A$, respectively.
Differences in the copy numbers between individual plants (A$\mathrm{H})$ were determined by a one-way analysis of variance (ANOVA) followed by a Tukey's post hoc test and indicated by an asterisk $(*)$. Error bars represent standard deviation $(n=3)$

analyses (CCA) based on TRFLP community profiles were carried out to evaluate the effects of tank slurry properties on microbial communities in tank bromeliads. Carbon, nitrogen and oxygen concentrations together with $\mathrm{pH}$ affected the bacterial, archaeal, methanogenic and methanotrophic community in tank bromeliads explaining $27 \%, 28 \%, 32 \%$ and $30 \%$ of their variability, respectively (Fig. 4 a-d). Variations in community compositions were significantly explained by the first CCA axis $(P \leq 0.01)$. The first axis sorted the bacterial, archaeal and methanogenic community composition along a gradient from high $\mathrm{C}$ and $\mathrm{N}$ and low $\mathrm{pH}$ and oxygen concentrations to tank substrates with low $\mathrm{C}$

b

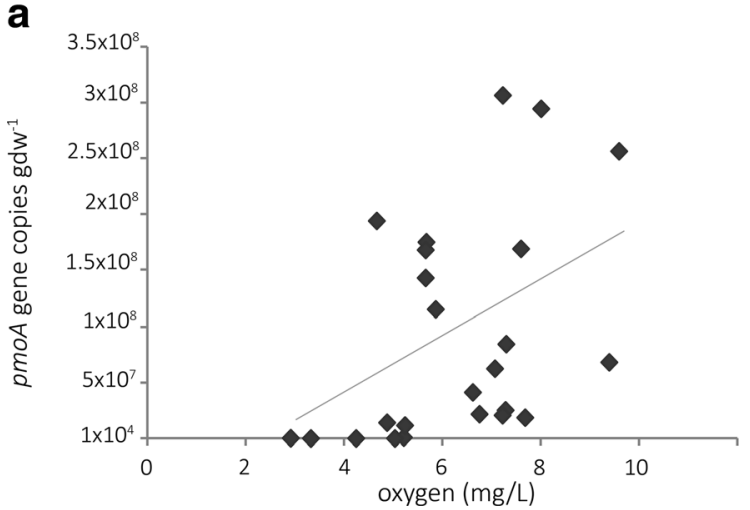

Fig. 2 a Linear regression showing the relationship between oxygen concentration and $p m o A$ gene copy numbers in tank slurries of W. gladioliflora $\left(\right.$ pmoA copies $=-6.5 \times 10^{7}+2.5 \times 10^{7} \times$ oxygen concentration; adj. $\left.\mathrm{r}^{2}=0.15 ; p=0.03 ; n=24\right)$. b Temporal

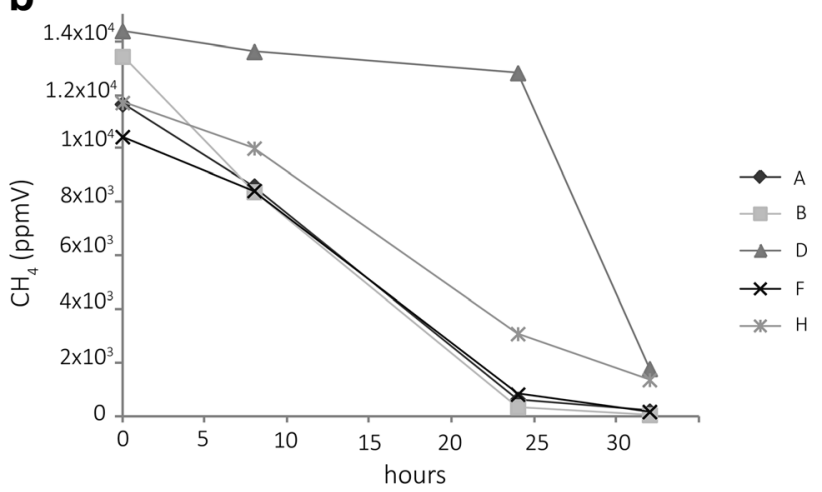

change of $\mathrm{CH}_{4}$ concentration in the headspace of flasks with tank slurry sampled from five plants of the species $W$. gladioliflora (A, B, D, F, H). 
a

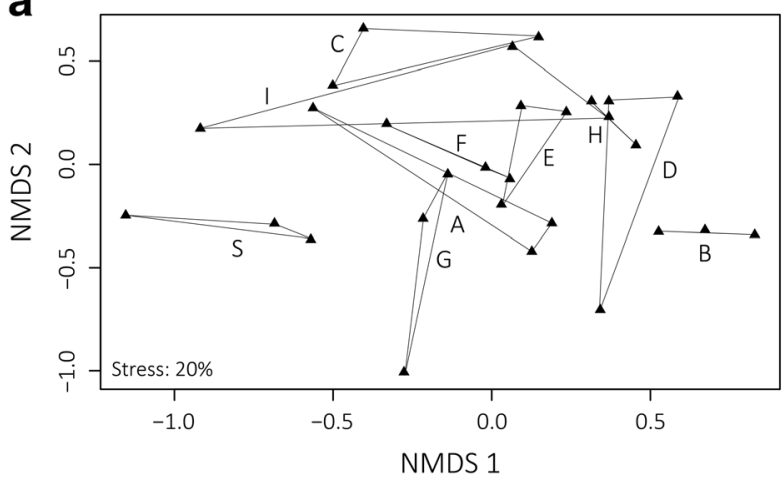

C

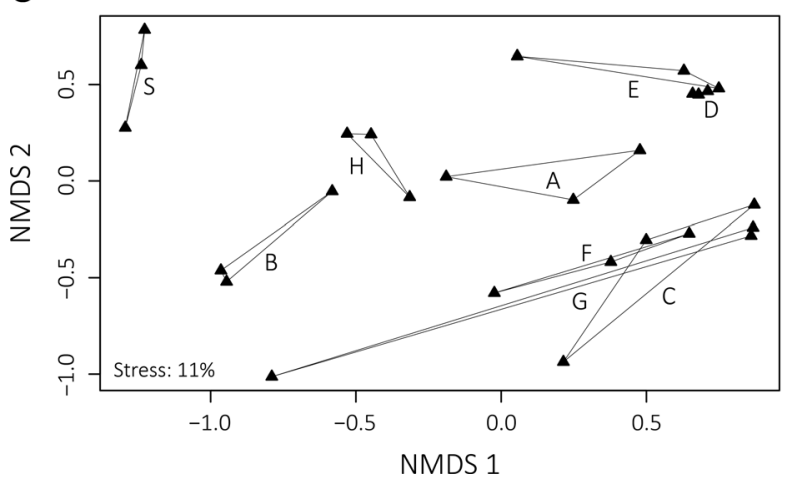

Fig. 3 Non-metric-multidimensional scaling analysis of the microbial community composition in bromeliad tank substrates of W. gladioliflora based on Bray-Curtis dissimilarities using TRFLP profiles of the bacterial 16S rRNA gene (a), archaeal 16S rRNA gene (b), methanogenic marker gene $m c r A$ (c) and methanotrophic marker gene pmoA (d). Three replicates per plant (A-H) are

and $\mathrm{N}$, and high $\mathrm{pH}$ and oxygen concentrations. Carbon concentration was a fundamental factor controlling the bacterial, archaeal and methanogenic community composition (Table 2). For instance, more than $20 \%$ of the archaeal community variation was explained by carbon concentration in tank slurry. The methanotrophic community was mainly sorted by oxygen concentration (Fig. 4 d) which alone explained more than $13 \%$ of the variation (Table 2).

\section{Aerobic methane oxidation in Werauhia gladioliflora}

Considering the observation that the slurries were well mixed within each bromeliad we used pooled slurry from different leaf axils of one plant to investigate the potential of methane oxidation. Aerobic methane oxidation was investigated in tank slurries from five plants during incubation experiments. Methane concentration $(\mathrm{ppm})$ in the headspace of all incubation flasks

\section{b}

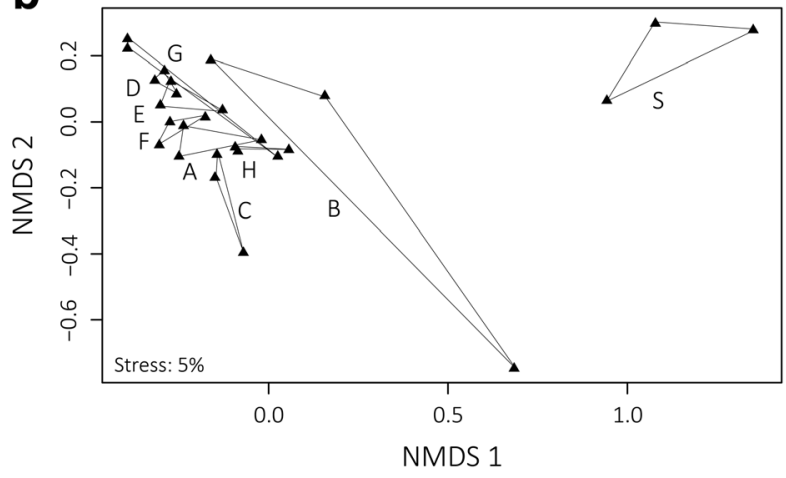

d

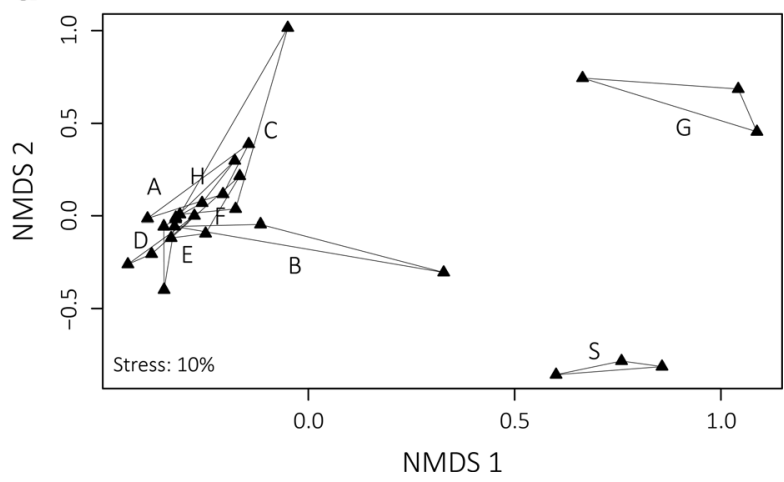

connected to a triangle and represent the community in a single tank bromeliad and the respective microbial community in nearby sampled soil (S). The closer two points are the more similar they are in community composition. The stress values (in \%) indicate the lack of the fit between the dimensional mapping of the dissimilarities and the original dissimilarities

decreased with time (Fig. 2b). The oxidation rates ranged between 25 and $62 \mu \mathrm{g} \mathrm{CH}_{4} \mathrm{gdw}^{-1} \mathrm{~h}^{-1}$ (Table 3).

\section{Discussion}

In this study, copy numbers of the methanogenic marker gene $m c r A$ in Costa Rican tank bromeliads were as high or even higher than those in a flooded rice field soil (Watanabe et al. 2009; Ma et al. 2012), the latter one representing a major source of atmospheric methane (Conrad 2002). Interestingly, methane oxidizing bacteria, quantified by the methanotrophic marker gene $p m o A$, were also found in all eight tank slurries in numbers that were in the same range as observed in wetland sediments or rice field soils (DeJournett et al. 2007; Wu et al. 2009). Aerobic methanotrophic bacteria are a highly specialized group of microbes using methane as sole source of energy and carbon (Hanson and 
a

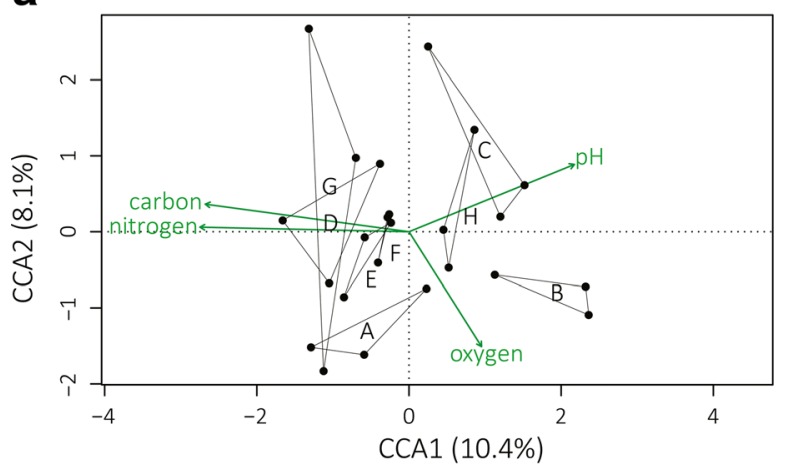

C

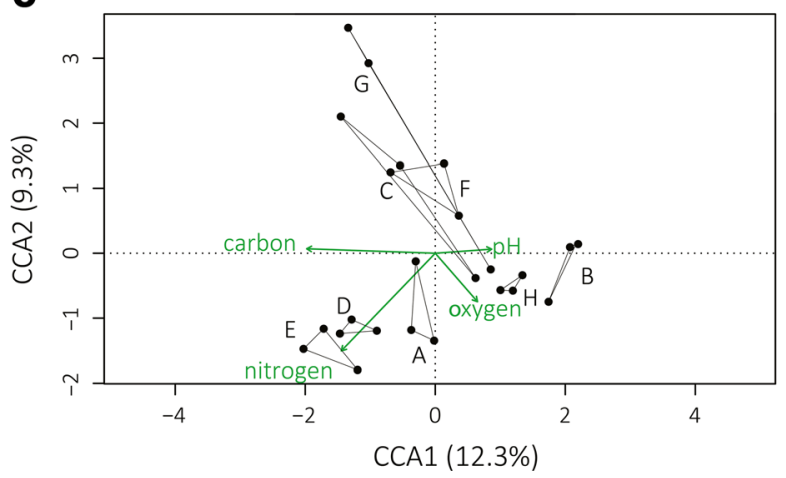

Fig. 4 Ordination of the bacterial (a), archaeal (b), methanogenic (c) and methanotrophic (d) community across the axis of a canonical correspondence analysis based on TRFLP community profiles. Three replicates per plant $(\mathrm{A}-\mathrm{H})$ are connected to a triangle

Hanson 1996; Murrell and Jetten 2009) and therefore potentially mitigate methane emission (Frenzel et al. 1990). The abundance of the $p m o A$ gene was positively correlated with the concentration of oxygen which serves as electron acceptor in methane oxidation and together with methane concentration limits methane oxidation activity. In summary, the presence of methanogens and methanotrophs in all eight individual bromeliads indicates the operation of both methane formation and methane oxidation in bromeliad tanks. We cannot exclude potential anaerobic $\mathrm{CH}_{4}$ oxidation processes but the operation of aerobic $\mathrm{CH}_{4}$ oxidation was confirmed by the decrease of $\mathrm{CH}_{4}$ concentration during the incubation of tank slurry under aerobic conditions. Our results support the hypothesis that methanotrophic bacteria are active in tank bromeliads especially when tank slurry is exposed to oxygen. Tank bromeliads are in general very efficient in maintaining water in their tanks and therefore may create anoxic niches where methanogenesis can occur. However, tank b

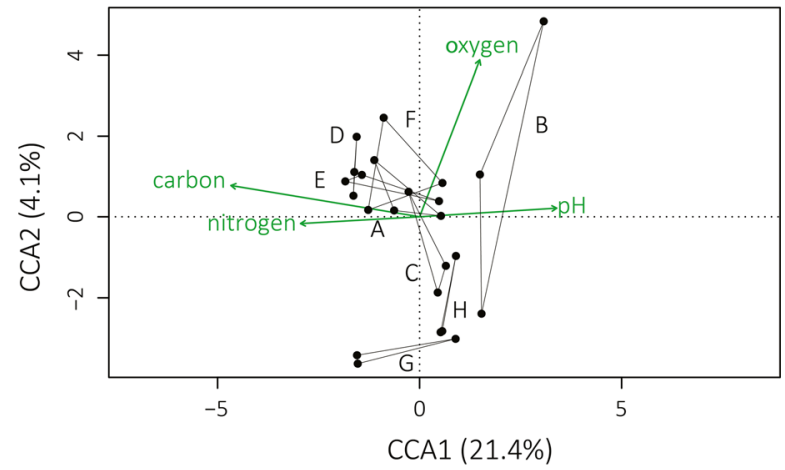

d

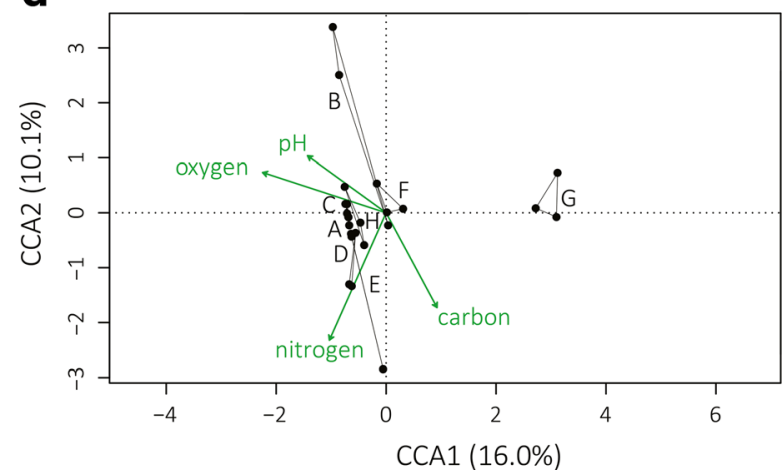

and represent the community in a single tank bromeliad of the species W. gladioliflora. The shared effect of carbon, nitrogen, oxygen concentration and $\mathrm{pH}$ of tank slurry on the respective community was for each model significant

slurries can be regularly exposed to oxygen and during periods of droughts tank slurries can completely dry out (Zotz and Thomas 1999). With the addition of $1 \% \mathrm{CH}_{4}$ we solely targeted low-affinity methanotrophs that are adapted to grow at high $\mathrm{CH}_{4}$ concentrations (Dunfield 2007). Along with dry periods methane emission decreases in tank slurries (Brandt et al. 2014) that may also favor the activity of high-affinity methanotrophs in bromeliad tanks.

Epiphytic bromeliads increase the volume of arboreal carbon storage by creating catchments in which litter accumulates until it is decomposed (Nadkarni 1994). Pittl et al. (2010) detected higher bacterial cell numbers in this decomposed litter within tank bromeliads $\left(\geq 10^{10}\right.$ copies $\mathrm{gdw}^{-1}$ ) than in tropical canopy soils (taken from the humus pockets generated around tank bromeliad roots) or terrestrial soil, the latter showing the lowest abundance. In this study, bacterial copy numbers in tank bromeliad slurry were found to be up to one order of magnitude higher $\left(\leq 1.8 \times 10^{11}\right.$ copies $\left.\mathrm{gdw}^{-1}\right)$ than in 
Table 2 Relative contribution of each environmental variable to the total constrained variation for the bacterial, archaeal, methanogenic and methanotrophic microbial community composition in bromeliad tank slurry of $W$. gladioliflora

\begin{tabular}{llll}
\hline Community & Variable & $\%$ Explained & $P$-value \\
\hline Bacteria & Carbon & 10.0 & $0.005^{*}$ \\
& Nitrogen & 7.3 & $0.005^{*}$ \\
& $\mathrm{pH}$ & 8.4 & $0.01^{*}$ \\
& Oxygen & 6.6 & $0.03^{*}$ \\
Archaea & Carbon & 20.8 & $0.005^{*}$ \\
& Nitrogen & 9.7 & 0.06 \\
& pH & 11.8 & $0.03^{*}$ \\
Methanogens & Oxygen & 5.2 & 0.32 \\
& Carbon & 11.25 & $0.05^{*}$ \\
& Nitrogen & 10.41 & $0.01^{*}$ \\
& pH & 6.9 & 0.15 \\
& Oxygen & 5.6 & 0.20 \\
Methanotrophs & Carbon & 7.7 & 0.11 \\
& Nitrogen & 10.9 & $0.01^{*}$ \\
& pH & 7.7 & 0.14 \\
& Oxygen & 13.3 & $0.01^{*}$ \\
\hline
\end{tabular}

$*=$ significant

the study by Pittl et al. (2010). Our results support the assumption that tank bromeliads may provide an ideal habitat for microorganisms in the canopy of neotropical forests (Goffredi et al. 2011b).

Beside differences in microbial community size between tank slurry and soil samples (Pittl et al. 2010), the taxonomic compositions also differed. These differences may be explained by habitat-specific conditions. We found a 8-fold higher carbon and 6-fold higher nitrogen content in the tank slurries than in the adjacent soil samples. Also water conditions between bromeliads and nearby located ponds were previously described to be

Table 3 Methane oxidation rates in five bromeliad tank slurries of W. gladioliflora

\begin{tabular}{ll}
\hline Bromeliad & $\mathrm{CH}_{4}$ Oxidation rate $\left(\mu \mathrm{gdw} \mathrm{h}^{-1}\right)$ \\
\hline A & 24.9 \\
B & 28.0 \\
D & 42.8 \\
F & 62.4 \\
H & 25.1 \\
Average $( \pm \mathrm{SE})$ & $36.6 \pm 7.2$ \\
\hline
\end{tabular}

$S E=$ standard error different. For instance, some aquatic invertebrates, like the bromeliad ostracod (Elpidium bromeliarum) were only found in tank bromeliads (Lopez et al. 2009), which differ in terms of specific composition compared to nearby ponds and swamps (Little and Hebert 1996).

Consistent with our hypothesis, our results indicate that each tank bromeliad creates a unique island in the canopies with respect to its microbial community. Within one individual bromeliad, however, microbial community structure showed a negligible variability probably due to mixing events caused by rainfall or animal interactions. The microcosms of tree holes face episodic mixing of nutrients due to stemflow (Walker et al. 1991). This may also be possible for tank bromeliads. The income of rainwater probably causes turbulences and therefore results in uniform conditions within the whole plant and in the establishment of similar microbial communities in each leaf axil. Sampling time points or sampling intervals may play a major role in order to detect controls on microbial community composition in tank bromeliad wetlands. In contrast to other studies, which lasted up to years (Carrias et al. 2001; Goffredi et al. 2011b; Carmo et al. 2014), our study captured only a snapshot in time. However it is to be emphasized, that due to different water availabilities the microbial community composition in tank slurry can dramatically change even within days (Brandt et al. 2014). Here, all tank slurry samples were taken within three days to limit further variations (e.g. seasonal changes, changes in water availability) revealing that the microbial community composition did not differ between leaf axils of a single plant but between individual plants although they belonged to the same species and grew in the same habitat patch. The bacterial and methanogenic communities showed thereby a more distinct clustering between tank slurries than the archaeal or methanotrophic communities did.

The archaeal community was dominated by a 393-bp TRF. In former studies this TRF was assigned to the hydrogenotrophic methanogens Methanomicrobiales or Methanocellales (Brandt et al. 2014; Martinson et al. 2010). The methanotrophic community was dominated by a 245-bp TRF (Supplementary Fig. S1d) and did not differ in its composition when one individual was excluded from the statistical analysis. In a previous study this 245-bp TRF was assigned to type-II methantotrophs consisting of various genera of methanotrophic bacteria (e.g. Methylocystis, Methylosinus; Lüke 2010). DNA fingerprinting, although a reliable and highly 
reproducible technique and frequently used for soils and marine environments, shows here a limited phylogenetic resolution for the methanotrophic community. Nevertheless, TRFLP analysis for the bacterial, archaeal and methanogenic community seem to be sufficient to reveal significant differences in community compositions between tank slurries. A high bacterial diversity and variability were also observed for other tank bromeliad species (Carmo et al. 2014) and habitats within tropical canopies. Differences in bacterial communities within and between tree species were reported by Lambais et al. (2006) investigating the phyllosphere from tree canopies of the Atlantic forests. This pre-existing variability of microbial organisms colonizing the tree phyllosphere may in turn favor the development of unique microbial community compositions in tank bromeliads since incoming leaves serve as nutrient input. Lambais et al. (2006) explained the variations in community compositions due to different leaf ages, location in the canopy, light incidence, and microclimate conditions that influence the leaf environment. Also the individual location of a bromeliad may therefore play an important role and influences the receipt of water, leaf litter, nutrient, light radiation (Guimaraes-Souza et al. 2006) and interactions with other organisms (e.g ants; Blüthgen et al. 2000). A habitat-associated effect was also observed investigating terrestrially and epiphytically grown tank bromeliads. Bromeliads associated with different forest strata, and their constrained environmental characteristics affected methane cycling (Martinson et al. 2010) and may indicate differing methanogenic community clusters within forest canopies. Several other studies further indicated that the morphology of a bromeliad species can influence the microclimatic characteristics as well as the community of insects and other macroinvertebrates in the tank of these plants (Jabiol et al. 2009; Marino et al. 2013). However, the influence of plant morphology was reduced in this study, since we used solely tank bromeliads of the same species and of similar size. Already at this level microbial community composition differed between plants.

To determine chemical factors that potentially influence the microbial community in the tank we investigated tank properties such as carbon, nitrogen and fatty acid concentration as well as $\mathrm{pH}$ and oxygen concentration which in turn may be influenced by the receipt of leaf litter, its quality/quantity and precipitation. Along with our hypothesis we clearly observed differences in $\mathrm{pH}$, carbon, nitrogen and oxygen concentration between plant slurries and especially carbon content revealed to be a major determinant for the bacterial, archaeal and methanogenic community composition. Carbon availability was already identified as one of the main drivers of microbial community structure in soil (Fierer et al. 2003) and Lopez et al. (2009) assumed that occasional organic matter inputs can induce a eutrophic condition in tank-bromeliads. In a previous study by Goffredi et al. (2011b) it was shown that $\mathrm{pH}$ has an effect on the bacterial community composition and that a low water content and therefore an increased oxygen exposure, affected the bacterial and archaeal community composition in tank bromeliad slurry (Brandt et al. 2014; Brandt 2015). In the present study, the microbial communities were further sorted along nitrogen concentrations in the tank slurry. Nitrogen is a limited factor for tank bromeliads. The plants receive nitrogen by mineralization of organic material from the canopy, from atmospheric sources (Stewart et al. 1995), by interactions with animals (Davidson and Epstein 1989; Leroy et al. 2013) or probably by microbial $\mathrm{N}_{2}$ fixation (Brighigna et al. 1992).

Finally, we assume that the place where a tank bromeliad develops is important, since carbon and nitrogen concentration of tank slurries are parameters which solely depend on (incoming) detritus as the basal resource and affect the inhabiting microbial communities.

Nevertheless, the explained variation of microbial communities was relatively low in this study. On the one hand this can be due to environmental factors that were not measured, such as water volume which was shown to affect invertebrate diversity and the archaeal and bacterial community composition and the pathway of methane formation in tank bromeliads (Dézerald et al. 2014; Brandt et al. 2014; Brandt 2015). On the other hand there is probably a large stochastic component connected with the ephemerality of the plants and dispersal dynamics (Farjalla et al. 2012; Jocque and Field 2014). Tank bromeliads are dynamic systems with high emigration rates since many inhabitants of bromeliads can fly or use vectors that are mobile (Lopez et al. 2002; Jocque and Field 2014).

\section{Conclusion}

According to our hypothesis we could show that each individual tank bromeliad plant created a unique habitat with a distinct microbial community characterized by 
the structure of four different genes (bacterial 16S rRNA gene, archaeal 16S rRNA gene, mcrA, pmoA). By contrast, these microbial communities were relatively homogenous within each individual plant. Our study confirmed the presence of methane-producing microorganisms. It further more demonstrated the presence of methanotrophic bacteria (characterized by pmoA) and of methane oxidation activity. Hence, a full methane turnover seems to be possible in tank bromeliad slurries.

Acknowledgments Open access funding provided by Max Planck Society. We gratefully thank the team of the Tropical Research Station La Gamba (Regenwald der Österreicher) for maintaining the field station, giving us the opportunity for accommodation and for providing us the liberty to use the lab equipment.

The project was financially supported by the Max Planck Society and the LOEWE (Synmicro) Program of the Ministry of Hessen. Many thanks to Björn Breidenbach for helpful discussions.

Open Access This article is distributed under the terms of the Creative Commons Attribution 4.0 International License (http:// creativecommons.org/licenses/by/4.0/), which permits unrestricted use, distribution, and reproduction in any medium, provided you give appropriate credit to the original author(s) and the source, provide a link to the Creative Commons license, and indicate if changes were made.

\section{References}

Angel R, Matthies D, Conrad R (2011) Activation of methanogenesis in arid biological soil crusts despite the presence of oxygen. PLoS One 6:20453

Atwood TB, Hammill E, Greig HS, Kratina P, Shurin JB, Srivastava DS, Richardson JS (2013) Predator-induced reduction of freshwater carbon dioxide emissions. Nat Geosci 6:191-194

Bak F, Scheff G, Jansen KH (1991) A rapid and sensitive ion chromatographic technique for the determination of sulfate and sulfate reduction rates in freshwater lake sediments. FEMS Microbiol Lett 81:23-30

Balke M, Gómez-Zurita J, Ribera I, Viloria A, Zillikens A, Steiner J, García M, Hendrich L, Vogler AP (2008) Ancient associations of aquatic beetles and tank bromeliads in the Neotropical forest canopy. Proc Natl Acad Sci U S A 105: 6356-6361

Blüthgen N, Verhaagh M, Goitía W, Blüthgen N (2000) Ant nests in tank bromeliads-an example of non-specific interaction. Insect Soc 47:313-316

Borcard D, Legendre P, Drapeau P (1992) Partialling out the spatial component of ecological variation. Ecology 73:1045-1055

Brandt FB (2015) Methanogenesis in phytotelmata: microbial communities and methane cycling in bromeliad tanks and leaf axils of oil palms. Dissertation, Philipps University of Marburg.

Brandt FB, Martinson GO, Pommerenke B, Pump J, Conrad R (2014) Drying effects on archaeal community composition and methanogenesis in bromeliad tanks. FEMS Microbiol Ecol 91:1-10

Brighigna L, Montaini P, Favilli F, Trejo AC (1992) Role of the nitrogen-fixing bacterial microflora in the epiphytism of tillandsia (Bromeliaceae). Am J Bot:723-727

Brouard O, Le Jeune AH, Leroy C, Cereghino R, Roux O, Pelozuelo L, Dejean A, Corbara B, Carrias JF (2011) Are algae relevant to the detritus-based food web in tank-bromeliads? PLoS One 6:e20129

Burggraf S, Huber H, Stetter K (1997) Reclassification of the Crenarchaeal orders and families in acordance with $16 \mathrm{~S}$ rRNA sequence data. Int J Syst Evol Microbiol 47:657660

Carmo FL, Santos HF, Peixoto RS, Rosado AS, Araujo FV (2014) Tank bromeliad water: similar or distinct environments for research of bacterial bioactives? Braz J Microbiol 45:185-192

Carrias JF, Cussac ME, Corbara B (2001) A preliminary study of freshwater protozoa in tank bromeliads. J Trop Ecol 17:611-617

Conrad R (2002) Control of microbial methane production in wetland rice fields. Nutri Cycl Agroecosyst 64:59-69

Costello A, Lidstrom E (1999) Molecular characterization of functional and phylogenetic genes from natural populations of methanotrophs in lake sediments. Appl Environ Microbiol 65:5066-5074

Davidson DW, Epstein WW (1989) Epiphytic associations with ants. In: Vascular plants as epiphytes. Springer, Berlin Heidelberg, pp. 200-233

DeJournett TD, Arnold WA, LaPara TM (2007) The characterization and quantification of methanotrophic bacterial populations in constructed wetland sediments using PCR targeting 16S rRNA gene fragments. Appl Soil Ecol 35:648-659

Dézerald O, Talaga S, Leroy C, Carrias JF, Corbara B, Dejean A, Céréghino R (2014) Environmental determinants of macroinvertebrate diversity in small water bodies: insights from tank-bromeliads. Hydrobiologia 723:77-86

Dunbar J, Ticknor LO, Kuske CR (2001) Phylogenetic specificity and reproducibility and new method for analysis of terminal restriction fragment profiles of 16S rRNA genes from bacterial communities. Appl Environ Microbiol 67:190-197

Dunfield PF (2007) The soil methane sink. In: Greenhouse Gas Sinks, UK:CABI Publishing, pp. 152-170

Farjalla VF, Srivastava DS, Marino NA, Azevedo FD, Dib V, Lopes PM, As R, Bozelli RL, Esteves FA (2012) Ecological determinism increases with organism size. Ecology 93:1752-1759

Fierer N, Schimel JP, Holden PA (2003) Variations in microbial community composition through two soil depth profiles. Soil Biol Biochem 35:167-176

Frenzel P, Thebrath B, Conrad R (1990) Oxidation of methane in the oxic surface layer of a deep lake sediment (Lake Constance). FEMS Microbiol Lett 73:149-158

Givnish TJ, Barfuss MHJ, Van Ee B, Riina R, Schulte K, Horres R, Gonsiska PA, Jabaily RS, Crayn DM, Smith JAC, Winter K, Brown GK, Evans TM, Holst BK, Luther H, Till W, Zizka G, Berry PE, Sytsma KJ (2011) Phylogeny, adaptive 
radiation, and historical biogeography in Bromeliaceae: insights from an eight-locus plastid phylogeny. Am J Bot 98: 872-895

Goffredi SK, Jang GE, Woodside WT, Ussler W III (2011a) Bromeliad catchments as habitats for methanogenesis in tropical rainforest canopies. Front Microbiol 2. doi:10.3389/ fmicb.2011.00256

Goffredi SK, Kantor AH, Woodside WT (2011b) Aquatic microbial habitats within a neotropical rainforest: bromeliads and $\mathrm{pH}$-associated trends in bacterial diversity and composition. Microb Ecol 61:529-542

Großkopf R, Janssen PH, Liesack W (1998) Diversity and structure of the methanogenic community in anoxic rice paddy soil microcosms as examined by cultivation and direct 16S rRNA gene sequence retrieval. Appl Environ Microbiol 64: 960-969

Guimaraes-Souza BA, Mendes GB, Bento L, Marotta H, Santoro AL, Esteves FA, Pinho L, Farjalla VF, Enrich-Prast A (2006) Limnological parameters in the water accumulated in tropical bromeliads. Acta Limnol Bras 18:47-53

Hanson RS, Hanson TE (1996) Methanotrophic bacteria. Microbiol Rev 60:439-471

Hofhansl F, Kobler J, Ofner J, Drage S, Pölz E-M, Wanek W (2014) Sensitivity of tropical forest aboveground productivity to climate anomalies in SW Costa Rica. Glob Biogeochem Cycles 28:1437-1454

Jabiol J, Corbara B, Dejean A, Céréghino R (2009) Structure of aquatic insect communities in tank-bromeliads in a eastAmazonian rainforest in French Guiana. For Ecol Manag 257:351-360

Jocque M, Field R (2014) Aquatic invertebrate communities in tank bromeliads: how well do classic ecological patterns apply? Hydrobiologia 730:153-166

Kitching RL (2001) Food webs in phytotelmata:"bottom-up" and "top-down" explanations for community structure. Annu Rev Entomol 46:729-760

Krumböck M, Conrad R (1991) Metabolism of position-labelled glucose in anoxic methanogenic paddy soil and lake sediment. FEMS Microbiol Lett 85:247-256

Lambais MR, Crowley DE, Cury JC, Büll RC, Rodrigues RR (2006) Bacterial diversity in tree canopies of the Atlantic forest. Science 312:1917-1917

Legendre P (2008) Studying beta diversity: ecological variation partitioning by multiple regression and canonical analysis. Plant Ecol1:3-8

Leroy C, Carrias JF, Corbara B, Pélozuelo L, Dézerald O, Brouard O, Dejean A, Céréghino R (2013) Mutualistic ants contribute to tank-bromeliad nutrition. Ann Bot 112:919-926

Little T, Hebert P (1996) Endemism and ecological islands: the ostracods from Jamaican bromeliads. Freshw Biol 36:327338

Lopez LCS, Rios, RI (2001) Phytotelmata faunal communities in sun-exposed versus shaded terrestrial bromeliads from southeastern Brazil. Selbyana 219-224. doi:10.2307/41760099

Lopez LCS, Gonçalves DA, Mantovani A, Rios RI (2002) Bromeliad ostracods pass through amphibian (Scinaxax perpusillus) and mammalian guts alive. Hydrobiologia 485: 209-211

Lopez LCS, Alves RRDN, Rios RI (2009) Micro-environmental factors and the endemism of bromeliad aquatic fauna. Hydrobiologia 625:151-156
Lüke, Claudia (2010) Molecular ecology and biogeography of methanotrophic bacteria in wetland rice fields. Dissertation, Philipps University of Marburg

Ma K, Conrad R, Lu Y (2012) Responses of methanogen $m c r A$ genes and their transcripts to an alternate dry/wet cycle of paddy field soil. Appl Environ Microbiol 78: 445-454

Marino NA, Srivastava DS, Farjalla VF (2013) Aquatic macroinvertebrate community composition in tank-bromeliads is determined by bromeliad species and its constrained characteristics. Insect Conserv Divers 6:372-380

Martinson GO, Werner FA, Scherber C, Conrad R, Corre MD, Flessa H, Wolf K, Klose M, Gradstein SR, Veldkamp E (2010) Methane emissions from tank bromeliads in neotropical forests. Nat Geosci 3:766-769

Murrell JC, Jetten MS (2009) The microbial methane cycle. Environ Microbiol Rep 1:279-284

Muyzer G, Teske A, Wirsen CO, Jannasch HW (1995) Phylogenetic relationships of Thiomicrospira species and their identification in deep-sea hydrothermal vent samples by denaturing gradient gel electrophoresis of $16 \mathrm{~S}$ rDNA fragments. Arch Microbiol 164:165-172

Nadkarni NM (1994) Diversity of species and interactions in the upper tree canopy of forest ecosystems. Amer Zool 34:70-78

Ngai JT, Srivastava DS (2006) Predators accelerate nutrient cycling in a bromeliad ecosystem. Science 314:963-963

Osborne CA, Galic M, Sangwan P, Janssen PH (2005) PCRgenerated artefact from 16S rRNA gene-specific primers. FEMS Microbiol Lett 248:183-187

Pittl E, Innerebner G, Wanek W, Insam H (2010) Microbial communities of arboreal and ground soils in the Esquinas rainforest, Costa Rica. Plant Soil 329:65-74

R Core Team (2013) R: A language and environment for statistical computing. R Foundation for Statistical Computing, Vienna, Austria. URL http://www.R-project.org/

Richardson BA (1999) The bromeliad microcosm and the assessment of faunal diversity in a Neotropical forest. Biotropica $31: 321-336$

Springer RIK, Sachs MS, Woese CR, Boone DR (1995) Partial gene sequences for the a subunit of methyl-coenzyme $M$ reductase $(m c r I)$ as a phylogenetic tool for the family Methanosarcinaceae. Int J Syst Bacteriol 45:554-559

Srivastava DS (2006) Habitat structure, trophic structure and ecosystem function: interactive effects in a bromeliad-insect community. Oecologia 149:493-504

Srivastava DS, Trzcinski MK, Richardson BA, Gilbert B (2008) Why are predators more sensitive to habitat size than their prey? Insights from bromeliad insect food webs. Am Nat 172:761-771

Stewart GR, Schmidt S, Handley LL, Turnbull MH, Erskine PD, Joly CA (1995) $15 \mathrm{~N}$ natural abundance of vascular rainforest epiphytes: implications for nitrogen source and acquisition. Plant Cell Environ 18:85-90

Stubner S (2002) Enumeration of 16S rDNA of Desulfotomaculum lineage 1 in rice field soil by real-time PCR with SybrGreen ${ }^{\mathrm{TM}}$ detection. J Microbiol Methods 50:155-164

Walker ED, Lawson DL, Merritt RW, Morgan WT, Klug MJ (1991) Nutrient dynamics, bacterial populations, and mosquito productivity in tree hole ecosystems and microcosms. Ecology:1529-1546 
Watanabe T, Kimura M, Asakawa S (2009) Distinct members of a stable methanogenic archaeal community transcribe $m c r A$ genes under flooded and drained conditions in Japanese paddy field soil. Soil Biol Biochem 41:276-285
Wu L, Ma K, Lu Y (2009) Rice roots select for type I methanotrophs in rice field soil. Syst Appl Microbiol 32:421-428

Zotz G, Thomas V (1999) How much water is in the tank? Model calculations for two epiphytic bromeliads. Ann Bot 83:183-192 